\title{
A Contrastive Schematic Analysis of COVID-19 Crisis Response Strategies in American, British and Egyptian Speeches from 11-14 March 2020
}

\author{
Hanaa Youssef Shaarawy Ismail \\ English Department \\ School of Linguistics and Translation \\ Badr University in Cairo (BUC) \\ hanaashaarawy@gmail.com
}

\begin{abstract}
Crisis response strategies have been subject to a plethora of research in the field of business and management to examine how stakeholders perceive crisis and respond to it. Moreover, Van Dijk's (1985) schematic analysis has been deployed to investigate the news whether printed or broadcasted. Some articles have examined Van Dijk's news schemata framework in the context of crisis, but no article, to date, has incorporated schematic analysis with Situational Crisis Communication Theory (SCCT). The purpose of this article is to integrate Van Dijk's schematic analysis encompassing the three levels of structure: macrostructure, superstructure and microstructure with different crisis response strategies to analyze the language of the speeches of Donald Trump, the former American President, Boris Johnson, the British Prime Minister and Mostafa Mabouly, the Egyptian Prime Minister, in response to coronavirus (COVID-19) pandemic during the period form 11 March 2020 to 14 March 2020. Findings reveal that there are common semantic macrostuctures and a common superstructure among the three speeches, but a different microstructure. The Egyptian Prime Minster was the speaker who took full responsibility of dealing with the crisis through using lexical structures that denote the "concern" and "internalizing information" response strategies. The lexicon of Trump is characterized by "self-enhancing communication" strategies that boast his Administration, and Johnson's speech is unique in using the "adjusting information" strategy that unveils his psychological disturbance in dealing with the crisis. The article is an attempt to delve into the characteristics of the language of different politicians during crisis time.
\end{abstract}

Keywords: macrostructure, superstructure, microstructure, situational crisis communication theory, Trump, Johnson, Madbouly 


\section{Introduction}

Coombs (1999) defined crisis as "an event that is an unpredictable, major threat that can have a negative effect on the organization, industry, or stakeholders if handled improperly" (as cited in Coombs, 2010, p. 18). This definition applies to corona virus (COVID-19) pandemic that has been sweeping the world since the end of 2019 given that it is an unexpected event that poses a huge threat not only to organizations but to all humankind as well. However, different crisis response strategies have been presented, in the literature, in the field of business and management to help stakeholders deal with organization crises and save their reputations to retain their public self-image. Moreover, Van Dijk (1985) introduced news schemata with three structure levels: macrostructure, superstructure and microstructure to analyze news whether printed or broadcasted. This study aims at integrating Van Dijk's schematic analysis with different crisis response strategies to explore the language of Donald Trump, the former American President, Boris Johnson, the British Prime Minster and Mostafa Mabouly, the Egyptian Prime Minster pertaining to coronavirus during the period from 11-14 March 2020.

\section{Review of literature}

Van Dijk's (1985) levels of structural analysis have been utilized by many researchers in different fields. For example, Esfehani (2013) combined macrostrucure and microstructure and created macrofiction. Zhang, Pan, and Zhang (2014) conducted a contrastive analysis on the superstructure level among three news stations: VOA, BBC and NPR. Al-Saaidi et al. (2016) examined the macrostructure and the microstructure in terms of lexicalization in the discourse of incitement. Pratiwi \& Refnaldi (2018) explored the macrostucture and superstructure in the speeches of Indonesian presidents. Olagunju (2019) investigated the macrostructure and microstructure of football texts. Mardikantoro et al. (2020) analyzed the macrostructure and the superstructure in the discourse of corruption in Indonesian newspapers.

COVID-19 has also been subject to ample research since its emergence. Social interactions were investigated during COVD-19. For example, Katila, Gan, and Goodwin (2020) examined social distancing among politicians; and Mondada et al. (2020) examined the social activity of paying during the pandemic. Abbas (2020) used Van Dijk's news schematic analysis to show how the pandemic was exploited for ideological and political purposes in the American New York Times and the Chinese Global Times newspapers, and Prieto_Ramos 
et al. (2020) discussed how naming the disease by the World Health organization (WHO) and by newspapers implied social and ideological beliefs. Chen et al. (2020) tracked the development of the data set of the virus on Twitter as a social media platform. In addition, Recuero and Soares (2020) tackled the disinformation of discourse when discussing COVID-19's cure on Twitter.

On the other hand, research on crisis communication is abundant (e.g., Cheng, 2016; Coombs, 2007; Coombs and Holladay, 2005; Coombs and Holladay, 2007; Kochigina, 2020; Kyrychok, 2017; Raupp, 2019; Xu, 2020), and some studies were conducted to apply critical discourse analysis to crisis (e.g., Dunn \& Eble, 2015). Nonetheless, no study, to the researcher's knowledge, has integrated crisis communication theory with Van Dijk's schematic analysis, the focus of the present study.

\section{Theoretical background}

This article is an attempt to integrate Van Dijk's schematic analysis with the Situational Crisis Communication Theory (SCCT). In what follows, both frameworks are briefly discussed.

\section{Van Dijk's Schematic Analysis}

Van Dijk (1988) provided an analytical framework for analyzing the discourse of the news. This framework has three levels of structural analysis: two levels that belong to the "global structure" and another level which is the "local structure". The global structure includes two levels: "macrostructure" and "superstructure". The macrostructure or "thematic structure" has to do with the topic or theme of discourse. Van Dijk (1985) asserted that this thematic structure is realized through three summarizing principles called "macrorules": "deletion", "generalization" and "re-(construction)" (p. 76), and he added that the macrostructure is delineated from the cognitive construction of background knowledge. On the other hand, Van Dijk (1988) maintained that the superstructure or "schemata" has to do with the rules and conventions that govern the organization of meaning in discourse. Local structure, additionally, includes the "microstructure" that tackles the sentential level of analysis in discourse from different linguistic perspectives as semantic, syntactic, stylistic, rhetorical, etc. 


\section{Situational Crisis Communication Theory (SCCT)}

Situational Crisis Communication Theory (SCCT) was "developed as a research-based guide for selecting crisis response strategies ... [that are] appropriate to the characteristics of the crisis situation" (Coombs, 2006, p. 242).

SCCT tackles three fundamental components: "the crisis situation", "crisis response strategies" and "a system for matching the crisis situation and crisis response strategies" (Coombs 2006, p. 243). Regarding "the crisis situation", SCCT classified crises according to their level of severity into three categories under the label "crisis clusters". The first cluster is termed "victim cluster". In this type of cluster, the organization is also a victim to the crisis like when having an earthquake or an act of terrorism. The second cluster type is "accidental cluster" where the organization's actions have unintentionally led to a crisis like technical damages to equipment. The third cluster is the "preventable cluster" where the organization intentionally put people at risk like when violating the law (Coombs, 2006, p. 244).

Concerning the "crisis response strategies", SCCT maintains that after identifying the crisis and placing it in the appropriate cluster, the organization chooses a strategy to respond to it. Coombs (1995) introduced the "Attribution Theory" as a framework of managing crisis. The "Attribution Theory" refers to the three dimensions of "locus, stability and controllability" upon which people perceive events. "Locus refers to locus of control, whether the cause was internal or external to an actor". "Stability" discusses whether the cause of the event is permanent or momentary. "Controllability" examines whether the actor can control the cause or if the cause is beyond the actor's management. When the attributions are internal, controllable and stable, the people perceive the organization responsible for the crisis, and when they are external, uncontrollable and unstable, attributions of responsibility are minimized. The severity of the attributions of responsibility threatens the reputation of the organization. Whenever the reputation damage is escalated, the organization deals with the crisis as if it were of the following more severe and more damaging crisis cluster. SCCT provides organizations with three basic options as crisis response strategies: "deny, diminish and deal". The "deny" option affirms that no crisis exists, and it could be achieved by "attacking the accuser", "denying" the existence of the crisis or by "scapegoating". The "diminish" option lessens the "attributions of responsibility" and claims that the crisis is not severe. The "deal" option requires the organization to behave according to "societal norms/expectations". It is achieved by "ingratiation", "concern', "compassion", 
"regret" and/or "apology" (Coombs, 2006, pp. 245-249). "Ingratiation" is also one of the strategies used by managers to gain legitimation and comply with societal norms (Allen \& Caillouet, 1994). It encompasses three sub strategies: "self-enhancing communication" which could be achieved through "role model" and/or accepting "social responsibility"; "other-enhancing communication" like praising the audience to gain their approval; and "opinion conformity" that shows similarity of positive values and beliefs (p. 60).

Coombs (2006) delved into "matching the crisis situation with crisis response strategies" as the third component discussed by SCCT. Any crisis in the "victim cluster" requires "instructing information" only, since there is no "crisis responsibility" borne by the organization, and there is "little violation of societal norms" (p. 249). Instructing information can be realized by one of three ways: what happened in the crisis, what people need to do to "protect" themselves from any harm, or what measures the organization should undertake to "correct" the situation and/or "prevent" it from happening again (p. 246). On the other hand, crises in the "accidental cluster" require the "diminish" response strategy, since there are some "attributions of responsibility", and the "violation of the societal norms" is greater than those of the "victim cluster" (p. 249). Crises in the "preventable cluster", need the "deal" response strategy given that the "attributions of responsibility" are very strong, and there are severe "violations of societal norms" (p. 249).

Coombs and Holladay (2005) incorporated emotions with the type of crisis. Sympathy from non-victims is aroused towards organizations that experience the "victim cluster" crisis type, but no strong emotions are provoked towards the "accidental cluster" crises since the "attributions of responsibility" are so low; whereas "anger" or "schednfreude (taking joy from the pain of the organization)" is produced in the "preventable cluster" crisis type because the organization allows the crisis to occur or because stakeholders may perceive some vengeance against the organization (pp. 269-270).

Since victims are created in any crisis, affect is also generated, and immediately after telling people how to physically protect themselves from the harm caused by a crisis in the "instructing information" stage, the organization tells people how to cope psychologically with the crisis, which is delineated in showing sympathy, in the "adjusting information" phase. After these two phases, the organization moves to saving its reputation by presenting information that help people formulate image about the organization, and this phase is called 
“internalizing information" (Coombs \& Holladay, 2007, pp. 300-301; Sturges, 1994, pp. 308-311).

\section{Theoretical Framework}

A preliminary analysis of the data of the present study reveals that the choice of lexicon is crucial in designating the intended crisis response strategy instantiated by each speaker. Regarding the syntactic, stylistic and rhetorical dimensions of analysis, they are not vital in any of the speeches. Since the audience of the three speeches are the public, sentences are simple and short, figures of speech are only used once in Trump's speech, "new clusters in the United States were seeded by travelers from Europe" and only repetition, as a rhetorical device, is used once by Johnson, "level with", and once by Madbouly, "prevention is the most important thing". Therefore, lexicalization is the only linguistic feature that is to be examined on the microstructure level of analysis for its vital importance, which conforms with Al-Saaidi et al. (2016) in stressing the importance of lexicalization as a microstructure dimension of analysis.

Moreover, since coronavirus is a global pandemic that is sweeping the whole world, and it is not ascertained that any country has accidently or intentionally caused it, the three speeches belong to the victim cluster crisis type. However, not only is "instructing information", that considers telling people what to do to protect themselves, present in the speeches as mentioned in the literature of this type of crisis, but also other strategies belonging to the "preventable cluster" crisis type are disclosed from the analysis. Accordingly, Van Dijk's (1998) schematic analysis incorporating macrostructure (topics and subtopics discussed in each speech), superstructure (overall organization of each speech) and microstructure (lexicalization) together with the SCCT encompassing the "deny" response strategy exemplified in denying responsibility of the crisis and "scapegoating" alongside with "instructing information" and "adjusting information" as two main strategies of the victim cluster crisis type beside the "deal" response strategy illustrated in "ingratiation", "apology" "concern", "compassion" and "internalizing information" are integrated in the present study to analyze the language of the speeches of American, British and Egyptian politicians in response to coronavirus (COVID-19) pandemic during the period from 11 March 2020 to 14 March 2020. The preliminary analysis did not show any instantiations of the "diminish" response strategy. 


\section{Research Questions}

To investigate the speeches of the three politicians from a schematic and a situational crisis communication perspective, the following research questions are posed:

1. What is the macrostructure that is manifested in each of these victim cluster crisis type?

2. How is the information presented in each victim cluster crisis type organized in the superstructure?

3. How does lexicalization, as an instantiation of the microstructure, reflect the appropriate crisis response strategy in each of the victim cluster crisis type?

An attempt to answer these research questions is presented in the following section.

\section{Methodology}

\section{Data}

Three speeches belonging to the victim cluster type represent the data of the current study. The first speech was delivered by the former American President Donald Trump on 11 March, 2020, and the speech transcript was downloaded from https://www.cpr.org/2020/03/11/transcript-video-presidentdonald-trump-addresses-the-nation-on-the-coronavirus-pandemicl. The second speech was delivered by the British Prime Minister, Boris Johnson, on 12 March 2020. The speech transcript was downloaded from https://www.gov.uk/government/speeches/pm-statement-on-coronavirus-12march-2020. The last speech was delivered by the Egyptian Prime Minister, Mostafa Madbouly, on 14 March 2020. Unfortunately, there was no transcript for this speech; so, the speech was watched on YouTube from https://www.youtube.com/watch?v=Pbvo5I4-Wn0 and transcribed. So, the speeches are dealt with as a type of written, not spoken, discourse; therefore, any instantiations of phonology or intonation do not lie within the scope of the present study. The three speeches were delivered at almost the same time where the global reaction to corona virus was assumingly to be the same.

\section{Data Analysis}


Each speech is analyzed with respect to the three thematic structures: macrostructure, superstructure and microstructure that reflect the different crisis response strategies in each speech.

\section{Speech 1 (Trump's speech on coronavirus)}

In terms of macrostructure, the speech is entitled "President Donald Trump Addresses The Nation On The Coronavirus Pandemic, March 11, 2020". Following this title, a summary of Trump's speech is provided. Two main topics are presented in this summary:

- $\quad$ the restrictions the US will impose on the European Union for not dealing promptly with coronavirus with the exclusion of UK, and

- $\quad$ the great measures the government will take to protect Americans.

The remaining topics in the speech are:

- $\quad$ Unique measures taken by the government

- The American administration is the best

- $\quad$ Observing the situation in China and South Korea

- $\quad$ Extra precautionary health measures to be taken by all Americans

- Great measures taken in providing financial aid to all working Americans

- Call for letting politics aside and unifying all efforts with love

In terms of superstructure, the speech goes as follows:

- $\quad$ Addressing the audience

- $\quad$ Reason of the talk

- $\quad$ Highlighting the unprecedented measures taken by the government

- $\quad$ Stressing the people's role

- $\quad$ Call for hope and unified efforts

- $\quad$ Praying for America

- $\quad$ Thanking the audience

On the microstructure level of analysis, lexicalization denotes that Trump used a combination of the crisis response strategies to address COVID-19. $\mathrm{He}$ started by the "deny" response strategy in the sense that he was not denying the existence of COVID-19, but that he was stressing that the United States had no responsibility for the spread of this virus. He used the sub strategy of scapegoating in blaming China for the emergence of the virus when saying "the corona virus outbreak that started in China and is now spreading throughout the world", and when describing the virus as "a foreign virus". He also blamed Europe for not acting promptly to the dissemination of the virus, which resulted in "new clusters in the United States were seeded by travelers from Europe", and Trump used the 
term "seeded" to emphasize the long-lasting harm caused by Europe, an outsider, in spreading the virus.

Trump, also, resorted to the "deal" response strategy in his choice of the lexical items by using "role model" as a sub strategy of "self-enhancing communication" in "ingratiation". Role modelling is used when he boasted his government by saying "our nation's unprecedented response, this is the most aggressive and comprehensive effort in modern history, we are responding with great speed and professionalism, our team is the best anywhere in the world, the first federally mandated quarantine in over 50 years, issued the highest level of travel warning, taking early intense actions, to take several strong actions, we are moving very quickly, smart action, they are the best, emergency action which is unprecedented, we have the greatest economy anywhere in the world, our banks and financial institutions are fully capitalized and incredibly strong, our unemployment is at a historic low, economic prosperity, we made a life-saving move with early action on China, no nation is more prepared or more resilient than the United States, we have the best economy, the most advance healthcare, and the most talented doctors, scientists, and researchers anywhere in the world". Additionally, the "deal" response strategy was used when he presented the measures that showed "concern" and "compassion" towards the victims by saying "we are marshaling the full power of the federal government and the private sector to protect our people", "provide financial relief for workers who are ill, quarantined, or caring for others due to coronavirus", "provide capital and liquidity to firms affected by the coronavirus", "help small businesses overcome temporary economic disruptions caused by the virus", "defer tax payments, without interest or penalties, for certain individuals and businesses negatively impacted", "provide Americans with immediate payroll tax relief". The "deal" response strategy is also apparent towards the end of speech through "otherenhancing communication" by saying "as history has proven time and time again, Americans always rise to the challenge and overcome adversity".

Since Trump's speech belong to the victim cluster crisis type, "instructing information" is also apparent in the lexicon of the speech when Trump told people what they should do to protect themselves, "the elderly population must be very, very careful", "nursing homes for the elderly suspend all unnecessary visits", "older Americans should avoid nonessential travel in crowded areas", "it is essential that everyone take extra precautions and practice good hygiene", "wash your hands, clean often-used surfaces, cover your face and mouth if you sneeze or cough", "if you are sick or not feeling well, stay home". 
"Internalizing information", as a "deal" response strategy, is also obvious in talking about the measures the government has undertaken, "to keep new cases from entering our shores, we will be suspending all travel from Europe to the United States for the next 30 days", "to waive copayments for coronavirus treatment, extend insurance coverage to these treatments, and to prevent surprise medical billing", "we are cutting massive amounts of red tapes to make antiviral therapies available in record time", "I signed into law and $\$ 8.3$ billion funding bill to help CDC and other government agencies fight the virus and support vaccines, treatments, and distribution of medical supplies", "we have issued guidance on schools closures, social distancing, and reducing large gatherings".

\section{Speech 2 (Johnson's speech on coronavirus)}

In terms of macrostructure, the second speech is entitled "Prime Minister's statement on coronavirus (COVID-19): 12 March 2020". The following topics are discussed:

- Many people are going to lose their loved ones

- Moving to the delay phase in the government plan

- $\quad$ Suspects and the elderly should stay at home

- $\quad$ Public events are not to be banned and schools are not to be closed

- $\quad$ People should use the internet instead of calling 111

- $\quad$ Apology for past deeds

- $\quad$ Offering money and supporting people and communities

- $\quad$ Reminding people to wash their hands

- A call for hope and unified efforts

In terms of superstructure, the speech goes as follows:

- $\quad$ Greeting the audience and thanking them for coming

- $\quad$ Coming from an emergency meeting

- $\quad$ Main topic of the talk

- $\quad$ Highlighting the measures taken by the government

- $\quad$ Stressing the people's role

- $\quad$ Call for hope and unified efforts

Johnson's lexicon, at the beginning of his speech, reflects the strategy of "adjusting information" as a victim cluster crisis type, since he was preparing his audience to the detrimental repercussions of COVID-19. He presented an anticipated gloomy, sympathetic picture of the situation "COVID 19 continues and will continue to spread across our country over the next few months, the number of cases will sharply rise, the worst public health crisis for a generation, 
alas, this disease is more dangerous, it's going to spread further, many more families are going to lose loved ones before their time".

After showing sympathy, Johnson resorted to the strategy of "concern" as a "deal" response strategy where he presented the government's plan to move from containing the disease to "delay its spread and thereby minimise the suffering, the government will do all we can to help you and your family during this period". He, then, moved to "internalizing information" in saying "we are considering the question of banning major public events, we have been guided by science, we will do the right thing at the right time, we are not closing schools now, we will continue to provide as much clear scientific and medical information as we can".

Johnson, then deployed "instructing information" to tell people what they should do to protect themselves "stay at home, we advise those over 70 against going on cruises, we advise against school international trips, not to call 111 but to use the internet information if they can, remember to wash our hands".

Towards the end of his speech, Johnson deployed the "deal" response strategy when "apologizing" for past deeds "we're not just going to be as you saw yesterday supporting the economy during this period" and when showing "compassion" by saying "we will be providing money and many other forms of support" and when showing ingratiation in the "self-enhancing strategy" in saying "just to remember, this country will get through this pandemic just as it has got through many tougher experiences before".

\section{Speech 3 (Madbouly's speech on coronavirus)}

The speech is characterized by discussing the reactive and proactive measures taken to protect people from cornonvirus. The speech conference is entitled "after suspending studies: Watch a press conference to the Prime Minister". Madbouly's speech was just a statement, and it was not a press conference since, according to Bhatia (2006), press conferences should include journalists asking questions after the speaker gives his statement (p. 177), which was not the case. Madbouly gave his speech and left. So, it is a speech. The main topic discussed in the speech is the reason for suspending studies in schools and universities for two weeks. The Prime Minister discussed the following subtopics:

- The government announced a three-stage plan based on scientific basis

- $\quad$ The government is now moving from stage 1 to stage 2 as a precautionary measure 
- $\quad$ Suspending studies in schools and universities for two weeks to avoid corona contact as a proactive and precautionary measure

- $\quad$ Sterilizing all institutions during this period

- $\quad$ People should limit being away from home to lessen all chances of corona contact

- $\quad$ People should take all health precautionary measures to avoid the spread of the virus

- $\quad$ The elderly should avoid crowded places as a precautionary measure

- The government is taking all proactive measures so as not to reach the situation that is happening worldwide

- $\quad$ Allocating money to face any repercussions of corona virus

In terms of superstructure, the speech goes as follows:

- Welcoming the audience

- $\quad$ Coming from a meeting

- $\quad$ Reason for the decision

- Highlighting the proactive and precautionary measures taken by the government

- $\quad$ Stressing the people's role

- Allocating money to face any anticipated repercussions of the virus

- Wrapping up

- $\quad$ Praying for Egypt

- $\quad$ Thanking the audience

Madbouly's started his speech with lexical structures that reflect the "deal" response strategy. He employed "internalizing information", for example, when he said, "we announced from the very beginning a clear three-stage plan, while following up the situation in the last ten days, we had to move to the second stage, suspending activities that have huge gatherings, with high honesty and transparency, we had to take a precautionary action, suspending studies in all schools and universities for two weeks, suspend all sports activities for the same time, sterilizing and purifying all our establishments, measures relating to performing prayers, we work according to a plan, we will spare no effort in taking any other precautionary and proactive measures, we meet on daily basis, we are here around the clock".

"Concern", as a "deal" response strategy is also so prominent in Madbouly's choice of lexical structures when saying, "we have to clearly and decisively face this issue as early as possible because the number of the young people in schools and universities represent $25 \%$ of the population, to protect the 
lives and health of our youth, to prevent contact in these vital establishments, to limit contact, to reduce contact, to prevent contact as much as possible, to protect our children and youth, to take precautionary measures to avoid, God forbids, any escalation or dissemination of the virus as that happened in some countries, to be more certain that we have no chances for the dissemination of the disease in these places, to protect and limit contact, to limit and prevent the process of dissemination, limit the spread of the disease, this case is concerned with the lives of Egyptians, we are fully committed to make all treatment and precautionary means available to our families and citizens in Egypt".

"Ingratiation" as a "deal response strategy is also apparent in Madbouly's lexical choices. He used the "self-enhancing communication" strategy when he stressed the first-person pronoun "I" in saying, "I also got into contact with the Minister of Youth and Sports, I told him, from the very beginning I asked their excellencies". He also used the "other-enhancing communication" strategy when saying, "An important merit is that we are a young nation".

"Compassion" as a "deal" response strategy is also used at the very end of Madbouly's speech when he said, "As per the instructions of his Excellency, the President, the government is to manage 100 billion pounds as an emergency reserve to face any negative repercussions".

Since Madbouly's speech belong to the victim cluster crisis type, it is not void of the strategy of "instructing information". This is obvious when saying, "to limit as much as possible getting out of the house, to take care of health and hygiene, to wash hands and face, to advise our fathers and all Egyptians of old age to avoid getting out or being in crowded places as much as possible, prevention is the most important thing".

\section{Results and Discussion}

In terms of macrostructure, the topics presented in the analysis above could be summed up into higher semantic macropropositions representing the macrostructure of the speeches (Table 1). Table 1 reveals that the main semantic macrostructures that are common in the three speeches are:

Table 1. The higher semantic macropropositions in the three speeches

\begin{tabular}{|l|c|c|c|}
\hline \multicolumn{1}{|c|}{ Theme } & Trump & Johnson & Madbouly \\
\hline Restrictions on other countries & $\sqrt{ }$ & & \\
\hline Our country is the best & $\sqrt{ }$ & & \\
\hline Measures taken and/or not to be taken to protect people & $\sqrt{ }$ & $\sqrt{ }$ & $\sqrt{ }$ \\
\hline Measures to be taken by people & $\sqrt{ }$ & $\sqrt{ }$ & $\sqrt{ }$ \\
\hline Financial aid and compensations & $\sqrt{ }$ & $\sqrt{ }$ & $\sqrt{ }$ \\
\hline
\end{tabular}




\begin{tabular}{|l|c|c|c|}
\hline Unifying efforts & $\sqrt{ }$ & $\sqrt{ }$ & $\sqrt{ }$ \\
\hline Many people are going to lose their loved ones & & $\sqrt{ }$ & \\
\hline Apology for a past deed & & $\sqrt{ }$ & \\
\hline
\end{tabular}

- Measures taken by the government to protect people

- Measures to be taken by people

- Financial aid and compensations

- Unifying efforts

Other macrostructures are idiosyncratic themes reflecting the policy and the ideology of each government. Trump, for example, discussed restrictions on other countries, and assured people that his Administration is the best, which exposes the American ideology that regards itself as the most superior power in the globe and hence has the right to rule the whole world. Johnson, on the other hand, mourned people in advance and apologized for a past deed, which foreshadows his anguish, fear and bewilderment. So, the macrostructure that is disclosed from the analysis of the three speeches comprises the same higher propositions, which answers the first research question.

Following from Van Dijk's (1988) idea that the superstructure is related to the macrostructure, the analysis reveals that the overall organization of the three speeches revolves around the following four moves:

- Greeting the audience

- Reason of addressing people

- Praying for the country and/or call for hope

- Thanking the audience

The second move, Reason of addressing people, is the "substance" of the three speeches that carries the main purpose for delivering the speech, and it is directly associated with all the information presented in higher macropropositions. Greeting the audience is considered the Opening of the speech, and Praying for the country and/or call for hope together with Thanking the audience are considered the Closing of the speech. Consequently, the superstructure of the three-victim cluster crisis type speeches contains an Opening, Substance and Closing, which answers the second research question.

In terms of microstructure, Table 2 shows the frequency of utterances including lexical structures with different crisis response strategies. Lexical items denoting the crisis response strategies associated with the "victim cluster type" 
and the "preventable cluster type" ("deal" response strategy) are only used in the three speeches. The analysis demonstrates that there are no traces of any lexical structures designating the "diminish" ("accidental") crisis response strategies. This is genuine since all the globe lies victim to corona virus, and all states need to face this virus with utmost measures to save the lives of their people; thence the strategies taken to face the virus, belong to the "preventable crisis cluster type" ("deal" response strategies), which complies with Coombs (2006) when stressing that crisis mangers should treat a severe crisis as if it were a member of the following stronger, crisis cluster type, and the "preventable cluster crisis type" is the strongest type. Nonetheless, lexical structures expressing the "victim cluster crisis type" specially the "instructing information" strategy are disclosed from the analysis (Table 2), since it is essential to tell people what to do to protect themselves, which goes in line with Coombs (2006) when assuring that "instructing information" is not a choice for any crisis manager and that it has to be provided.

Table 2. Frequency of utterances including lexical structures with different crisis response strategies

\begin{tabular}{|c|c|c|c|c|c|c|c|c|c|c|c|c|c|c|c|c|c|c|}
\hline \multirow{4}{*}{ Speech } & \multicolumn{6}{|c|}{ Victim cluster strategies } & \multicolumn{12}{|c|}{ Deal response strategies } \\
\hline & \multirow{2}{*}{\multicolumn{2}{|c|}{ Scapegoating }} & \multirow{2}{*}{\multicolumn{2}{|c|}{$\begin{array}{l}\text { Instructing } \\
\text { information }\end{array}$}} & \multirow{2}{*}{\multicolumn{2}{|c|}{$\begin{array}{c}\text { Adjusting } \\
\text { information }\end{array}$}} & \multicolumn{4}{|c|}{ Ingratiation } & \multirow{2}{*}{\multicolumn{2}{|c|}{ Concern }} & \multirow{2}{*}{\multicolumn{2}{|c|}{ Apology }} & \multirow{2}{*}{\multicolumn{2}{|c|}{ Compassion }} & \multirow{2}{*}{\multicolumn{2}{|c|}{$\begin{array}{l}\text { Internalizing } \\
\text { information }\end{array}$}} \\
\hline & & & & & & & \multicolumn{2}{|c|}{$\begin{array}{l}\text { Self-enhancing } \\
\text { communication }\end{array}$} & \multicolumn{2}{|c|}{$\begin{array}{c}\text { Other- } \\
\text { enhancing } \\
\text { communication }\end{array}$} & & & & & & & & \\
\hline & \# & $\%$ & \# & $\%$ & $\#$ & $\%$ & $\#$ & $\%$ & \# & $\%$ & $\#$ & $\%$ & $\#$ & $\%$ & $\#$ & $\%$ & \# & $\%$ \\
\hline Trump & 3 & 7.3 & 6 & 14.7 & $\ldots$ & - & 20 & 48.8 & 1 & 2.4 & 1 & 2.4 & - & - & 5 & 12.2 & 5 & 12.2 \\
\hline Johnson & L & $\ldots$ & 5 & 22.7 & 7 & 32 & 1 & 4.5 & 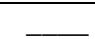 & 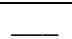 & 2 & 9.1 & 1 & 4.5 & 1 & 4.5 & 5 & 22.7 \\
\hline $\begin{array}{l}\text { Madbo } \\
\text { uly }\end{array}$ & - & - & 6 & 11.3 & - & - & 4 & 7.5 & 1 & 1.9 & 14 & 26.4 & - & - & 1 & 1.9 & 27 & 51 \\
\hline
\end{tabular}

When investigating Trump's speech, Table 2 shows that the highest percentage in the speech is found in the "deal" response strategy of "selfenhancing communication". Almost half of Trump's speech (about 49\%) is dedicated to lexical structures that signify his pride of his Administration and their place in superiority to the whole world. Table 2 also shows that Trump was the only one in the three speakers that used the strategy of "scapegoating" that puts full responsibility for the emergence of the virus and its dissemination on China 
and, then, Europe. So, what mattered to Trump was to prove that he is the best, and that he was not responsible for anything.

Regarding Johnson's speech, Table 2 demonstrates that the highest percentage in the speech is found in the "victim cluster crisis type" strategy of "adjusting information". Johnson's bewilderment and fear are reflected in 32\% of his lexical structures which shows that he was at a mess, and that he did not know how to react to the crisis appropriately. Johnson was the only speaker who resorted to this strategy. Moreover, he was the only speaker who used the "apology" strategy, which denotes that he has committed a wrong act that deserves apology.

Madbouly, on the other hand, used 51\% of his lexical structures as a "deal" response strategy of "internalizing information", which is the highest percentage among the three speeches. His aim was to stress the fact that the government is doing its best for the lives and safety of the people. Moreover, the "concern" strategy is also the highest among the three speeches (26.4\%) which foreshadows the full responsibility the government is bearing to face the virus albeit the fact that Egypt is also a victim to corona virus exactly as the United States and the United Kingdom. Consequently, the microstructure level of analysis differs among the three speeches, which answers the third research question.

All that has been presented designates that all the three levels of structure serve each other and are dependent on each other. The lexical structures unite to form semantic propositions that are arranged in the superstructure. This coincides with Van Dijk's (1998) asserting that there is always a relation among the three levels of structures.

\section{Conclusion}

The purpose of the present study was to integrate Van Dijk's schematic analysis with SCCT to analyze the speeches of Trump, Johnson and Madbouly during COVID-19 in the period between 11-14 March 2020. Findings indicated that the levels of macrostructure and superstructure are common among the three speeches; however, the microstructure level varies. The lexicon of Madbouly foreshadows the "concern" and "internalizing information" strategies, and that of Trump denotes "self-enhancing information"; whereas Johnson's is characterized by the "adjusting information" strategy. The analysis of the speeches also revealed that there are no traces of the "diminish" response strategy.

The study was not engaged in the phonological level of the speeches, since it tackles the speeches as written, not spoken discourse. So, it is recommended to 
conduct research on this aspect of analysis on the same speeches of the study and/or other speeches by the same politicians on the same topic. It is also recommended to conduct a diachronic research to trace the development or deterioration of the lexicon of the speakers after time passes and after people are getting used and coping with the existence of such a virus.

\section{References:}

Abbas, A. H. (2020). Politicizing the pandemic: A schemata analysis of COVID19 news in two selected newspapers. International Journal for the Semiotics of Law. DOI: 10.1007/s11196-020-09745-2

Allen, M. W. and Caillouet, R. H. (1994). Legitimation endeavors: impression management strategies used by an organization in crisis. Communication Monographs, 61(1), 44-62. DOI: 10.1080/03637759409376322

Al-Saaidi, S., K., Pandian, A., \& Al-Shaibani, G.K.S. (2016). The semantic macrostructures and lexicalizations in Osama Bin Laden's speech of incitement. Academic Research International, 7(3), 288-300. Retrieved from https://www.academia.edu/26635049

Bhatia, A. (2006). Critical discourse analysis of political press conferences. Discourse and Society, 17(2), 173-203. DOI:10.1177/0957926506058057

Chen, E., Lerman, K., \& Ferrara, E. (2020). Tracking social media discourse about the COVID-19 pandemic: Development of a public coronavirus Twitter data set. JMIR Public Health Surveill, 6(2). DOI: 10.2196/19273

Cheng, Y. (2016). How social media is changing crisis communication strategies: Evidence from updated literature. Journal of Contingencies and Crisis Management, 2(4). DOI: 10.1111/1468-5973.12130

Coombs, W.T. (1995). Choosing the right words: The development of guidelines for the selection of "appropriate" crisis response strategies. Management Communication Strategy, 8, 447-476. DOI: 10.1177/0893318995008004003

Coombs, W.T. (2006). The protective powers of crisis response strategies. Journal of Promotion Management, 12(3/4), 241-260. DOI: 10.1300/J057v12n03_13

Coombs, W.T. (2007). Protecting organization reputations during a crisis: The development and application of situational crisis communication theory. Corporate Reputation Review, 10(3), 163-176. Retrieved from https://link.springer.com/article/10.1057/palgrave.crr.1550049 
Coombs, W.T. (2010). Parameters for crisis communication. In W.T. Coombs \& S.J. Holladay (Eds.), The handbook of crisis communication (pp. 17-53). UK: Blackwell Publishing Ltd. DOI: 10.1002/9781444314885

Coombs, W.T. \& Holladay, S.J. (2005). An exploratory study of stakeholder emotion: Affect and crises. Research on Emotion in Organizations, 1, 263280. DOI :10.1016/S1746-9791(05)01111-9

Coombs, W.T. \& Holladay, S.J. (2007). The negative communication dynamic: Exploring the impact of stakeholder affect on behavioral intentions. Journal of Communication Management, 11(4), 300-312. DOI: $10.1108 / 13632540710843913$

Dunn, C. \& Eble, M. (2015). Giving voice to the silenced: Using critical discourse analysis to inform crisis communication theory. Journal of Business Ethics, 132, 717-735. DOI: 10.1007/s10551-014-2315-4

Esfehani, L. S. (2013). From macro and microstructures to an innovation: The microfiction structure. International Journal of English Language and Linguistics Research, 1(2), 13-30. Retrieved from https://www.eajournals.org/wp-content/uploads/FROM-MACRO-ANDMICROSTRUCTURES-TO-AN-INNOVATION-THEMACROFICTION-STRUCTURE.pdf

Katila, J., Gan, Y., \& Goodwin, M.H. (2020). Interaction rituals and "social distancing": New haptic trajectories and touching from a distance in the time of COVID-19. Discourse Studies, 22(4), 418-440. DOI: $10.1177 / 1461445620928213$

Kochigina, A. (2020). The parallel power in organizations' defense: Exploring faith-holders and their crisis communication. Public Relations Review, 46. DOI: $10.1016 /$ j.pubrev.2020.101950

Kyrychok, A.P. (2017). An impact of situational crisis-communication theory on the efficiency of investigations in the field of crisis communication. Humanities and Social Sciences, 5(19): 55-58. Retrieved from https://www.researchgate.net/publication/330541478

Mardikantoro, H. B., Siroj, M. B., \& Utami, E. S. (2020). Analysis of macrostructure and superstructure of corruption news discourse in newspapers. RETORIKA Jurnal Bahasa Sastra dan Pengajarannya 13(1), 22-29. DOI:10.26858/retorika.v13i1.10968

Mondada, L., Banninger, J., Bouaouina, S. A., Gauthier, G., Hanggi, P., Koda, M., Svensson, H., \& Tekin, B. S. (2020). Doing paying during Covid-19 
pandemic. Discourse Studies, 22(6), 720-752. DOI: $10.1177 / 1461445620950860$

Olagunju, S. (2019). Microstructural analysis of football texts. Journal of Literature, Languages and Linguistics, 55, 56-67. DOI: 10.7176/JLLL

Pratiwi, A. \& Refnaldi (2018). Macrostructures and superstructures patterns of Jakowi's speeches. E-Journal of English Language \& Literature, 7(4), 547-556. Retrieved from http://ejournal.unp.ac.id/index.php/jell

Prieto-Ramos, F., Pei, J., \& Cheng, L. (2020). Institutional and news media denominations of COVID-19 and its causative virus: Between naming polices and naming politics. Discourse \& Communication, 14(6), 635-652. DOI: $10.1177 / 1750481320938467$

Raupp, J. (2019). Crisis communication in the rhetorical arena. Public Relations Review, 45. DOI: 10.1016/j.pubrev.2019.04.002

Recuero, R., \& Soares, F. (2020). The disinformation discourse about COVID19's cure on Twitter: A case study [Abstract]. E-Compos. DOI: https://doi.org/10.1590/SciELOPreprints.84

Sturges, D. L. (1994). Communicating through crisis: A strategy for organizational survival. Management Communication Quarterly, 7(3), 297-316. DOI: $10.1177 / 0893318994007003004$

Van Dijk, T. A. (1985). Structures of news in the press. In T.A. Van Dijk (Ed.), Discourse and communication: New approaches to the analysis of mass media discourse and communication (pp. 69-93). New York: Walter de Gruyter. Retrieved from http://www.discourses.org/OldArticles/Structures\%20of\%20news\%20in\% 20the\%20press.pdf

Van Dijk, T. A. (1988). News as Discourse. New Jersey: Lawrence Erlbaum. Retrieved from http://www.discourses.org/OldBooks/Teun\%20A\%20van\%20Dijk\%20$\% 20$ News\%20as\%20Discourse.pdf

$\mathrm{Xu}$, J. (2020). Does the medium matter? A meta-analysis on using social media vs. traditional media in crisis communication. Public Relations Review, 46. DOI: 10.1016/j.pubrev.2020.10194

Zhang, X., Pan, Y., \& Zhang. M. (2014). Superstructure analysis in news stories - a contrastive study of VOA, BBC, and NPR news. Asian Social Science, 10(22), 199-209. DOI: 10.5539/ass.v10n22p199 


\title{
تحليل تخطيطى تقابلى لاستراتيجيات التعامل مع أزمة كوفيد - 19

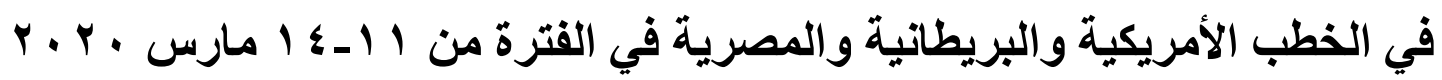

\author{
هناء يوسف شعر اوى اسماعيل \\ قسم اللغة الانجليزية \\ كلية اللغات و الترجمة، جامعة بدر بالقاهرة، القاهرة \\ hanaashaarawy@gmail.com
}

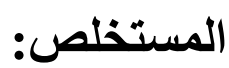

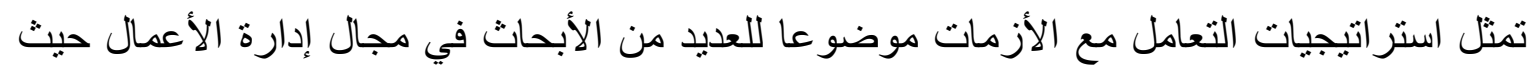

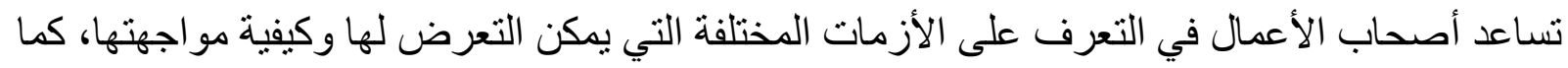

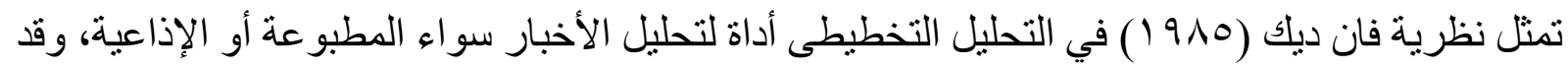

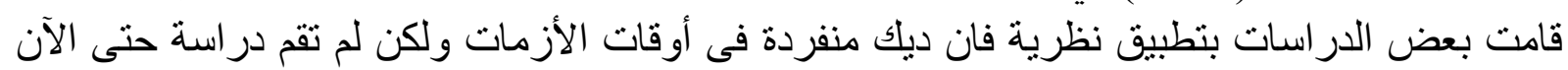

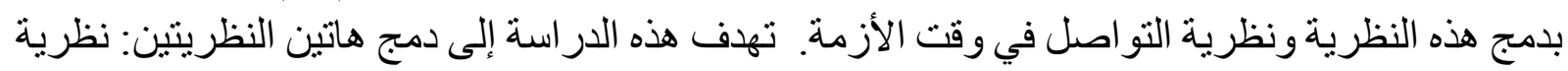

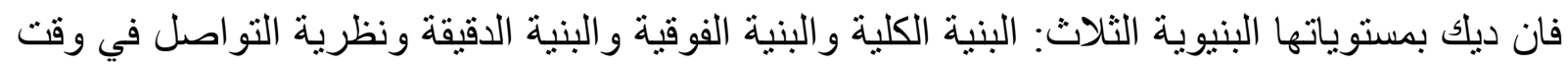

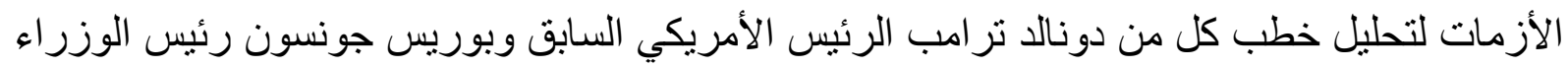

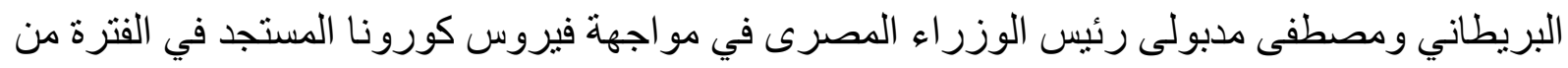

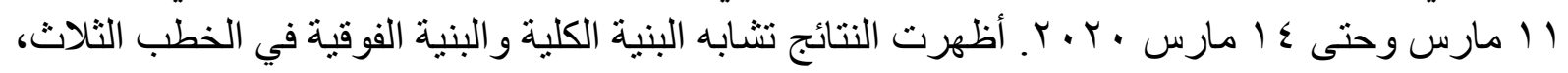

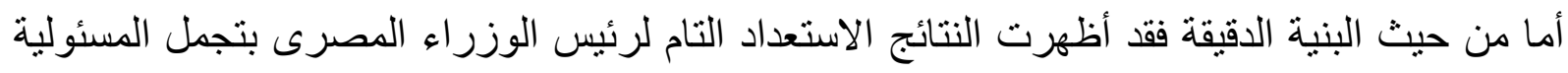

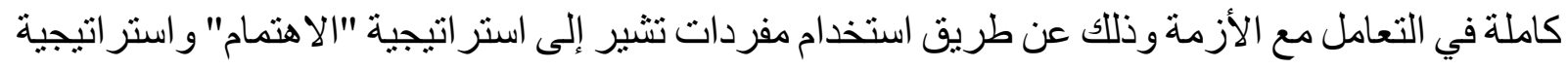

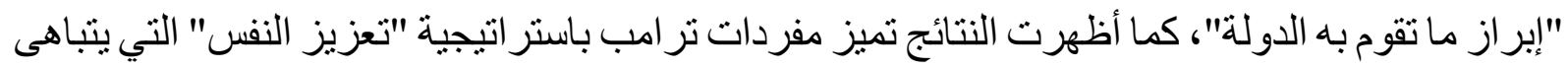

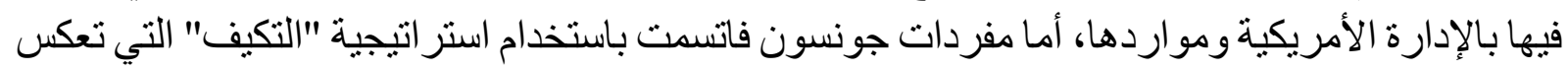

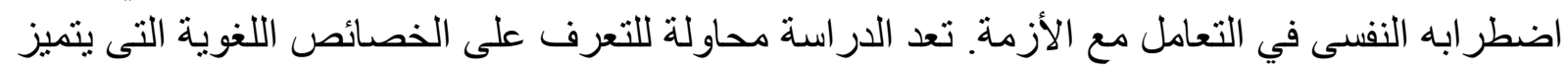
بها الساسة في أوقات الأزمات.

الكلمات الدالة: البنية الكلية، البنية الفوقية، البنية الدقيقة، نظرية التواصل في وقت الأزمة، نرامب، جونسون، مدبولى الكى 